\title{
Engineering a New Nation: Mahendra Raj and His Collaborations Across Disciplines
}

\author{
MOHAMED A. ISMAIL \\ Massachusetts Institute of Technology
}

\author{
CAITLIN T. MUELLER \\ Massachusetts Institute of Technology
}

\begin{abstract}
Mahendra Raj is an engineer that enjoys a challenge. Consequently, no two projects of his are the same. With a portfolio of over $\mathbf{2 5 0}$ projects and a career spanning nearly six decades, from Indian Independence to the time of this paper's writing, there is no simple explanation for who Raj works with or how he works with them. In an attempt to understand the range and extent of Raj's ability and influence on projects, this paper will examine three seminal projects from his early career. Each project will display a different facet of how Raj works with architects. The first will be Raj's close collaboration with Pritzker laureate, Balkrishna Doshi: Tagore Memorial Hall in Ahmedabad, completed in 1965. Second, the Hall of Nations and Halls of Industries, designed with Raj Rewal and Kuldip Singh, and completed in 1972 in New Delhi. Last, the Hindon River Mills, designed with Kanvinde and Rai, and built in 1973 in Ghaziabad. Each project shows a visionary engineering solution where the structure makes a bold statement and becomes integral to the architecture. Yet between them, differences emerge in how Mahendra Raj works with the architects. This paper explores those differences.
\end{abstract}

\section{INTRODUCTION}

On the eve of India's independence from British colonial rule Prime Minister Nehru gave one of the most important speeches of the 20th century, the Tryst with Destiny. Nehru began with the following:

Long years ago, we made a tryst with destiny, and now the time comes when we shall redeem our pledge, not wholly or in full measure, but very substantially. At the stroke of the midnight hour, when the world sleeps, India will awake to life and freedom. A moment comes, which comes but rarely in history, when we step out from the old to the new, when an age ends, and when the soul of a nation, long suppressed, finds utterance.

-Jawaharlal Nehru, August 14th, 1947

In a post-colonial India, those responsible for the design of India's built environment were searching for a new national identity, an architectural idiom for India's newfound position in the global arena. India was a nation with exciting potential born from a rich and expansive history, and her architecture was determined to declare this to the world. Amidst the construction boom across India, one of the most important events was the design and construction of Chandigarh, the new capital for a recently divided Punjab state under the leadership of Prime Minister Nehru.
While this undertaking is well known for introducing the SwissFrench architect, Le Corbusier, to India, it is also responsible for introducing one of India's most celebrated structural engineers to the world: Mahendra Raj. Through a study of his biography and writings, conversations with his colleagues and journalists, and an examination of three of his most acclaimed projects, this paper explores the nature of Mahendra Raj's collaborations with the designers of a newly independent India.

\section{LIFE, EDUCATION, AND TRAINING}

Mahendra Raj was one of eight children born in 1924 to a lower-middle class family in Gujranwala, in what is now Pakistan. Growing up, Raj was exposed to his father's work as a civil engineer for the Punjab Public Works Department (PWD) and often taken to site visits. Raj maintains that it was never his intention to become a civil engineer, stating "My father was determined to educate all his children properly and was eager that all five sons become civil engineers," (Raj et al. 2016). In 1946, Raj graduated with honors as a civil engineer from the Punjab College of Engineering and Technology in Lahore and joined the PWD in Lahore, working with stabilized soil for roads and buildings. The following year, India was granted independence from British rule and engineers at the PWD were asked whether they wished to work in the largely Hindu India or the newly formed Islamic Pakistan - Raj elected to work in India.

Seeing potential in the young engineer, the PWD moved Mahendra Raj to a rehabilitation cell that worked to construct housing for displaced middle-class families. Soon, the same cell was hired to lead construction in the new capital of Punjab, Chandigarh, where Raj was promoted to the position of Assistant Design Engineer. This became a catalyzing moment in Raj's career, a moment when he shifted from being a civil engineer to being a structural engineer. Until this point in time, Raj's experience was limited to civil work and infrastructure, working with construction site management and road maintenance. Raj recalls, "I got posted in the design cell of Chandigarh in late 1951/early 1952...I was assigned to work under the Executive Engineer, Gulzar Singh, who has been fortunate enough to go to Canada and acquire a Master's Degree in Structures... He gave me the American codes and design literature, introducing me to the art of structural design. In my four or five years in the PWD until then, I had not designed so much as a lintel!" Despite having never worked on buildings, Raj proved vital in the realization of Le Corbusier's High Court and Secretariat buildings. 
In an interview with architect Stephane Paumier, Mahendra Raj describes the experience of working with Le Corbusier, "What I learnt working for Corbusier is that even if you don't understand or if you feel what you have been asked to do can be done in a better way, speak up. Don't be shy or don't be afraid. At the most your ideas would be rejected, but there is nothing to lose - so, speak up" (Paumier and Raj 2014). And speak up is what he did; Raj spoke up to Le Corbusier, and many others throughout his sunsequent career. When Le Corbusier's design for the conoidal shell roof of the High Court proved difficult to design and build, Raj and Singh proposed an alternative cantilever system built in segments (figure 1). After a series of difficult discussions with the team of architects, their proposal was accepted and constructed. Likewise, in the Secretariat building, Raj proposed a more structurally feasible framing system for the façade. Raj writes, "This alignment of columns did not change the façade much but when I explained this to my seniors they were reluctant to make the request to Corbusier themselves. Instead they took me directly to him... He was fairly rude and told me to leave it with him. But a few days later I received a call that Corbusier wanted to see me. This time he was all smiles and charms." Once again, after some cajoling, Le Corbusier accepted his proposal and it was built to Raj's specifications (shown below).

Inspired by his first foray into structural engineering, Mahendra Raj decided to continue his education in the United States and enrolled in a Master's Degree in Structures at the University of Minnesota in 1955, nearly ten years after graduating from college. After receiving his Master's degree in 1956, Raj was hired to work with Amman \& Whitney, the New York-based engineering firm with a reputation in large-span structures. Working with Amman \& Whitney for three years, from 1956 to 1959, Raj was introduced to a series of structural precedents - sometimes the
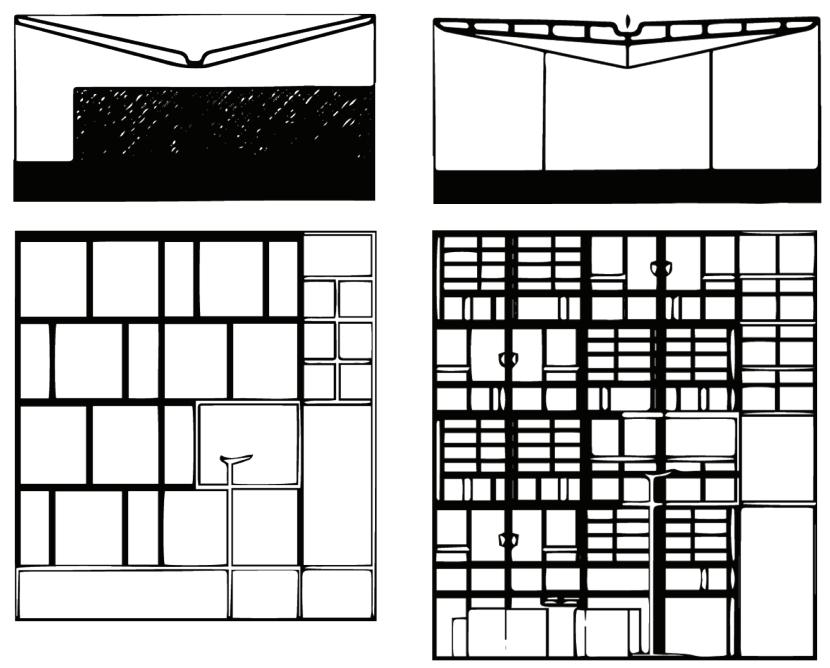

A

B

Figure 1. A, Original High Court roof parasol and Secretariat screen by LeCorbusier and $B$, final designs by Mahendra Raj. University of Chicago Press, 2016

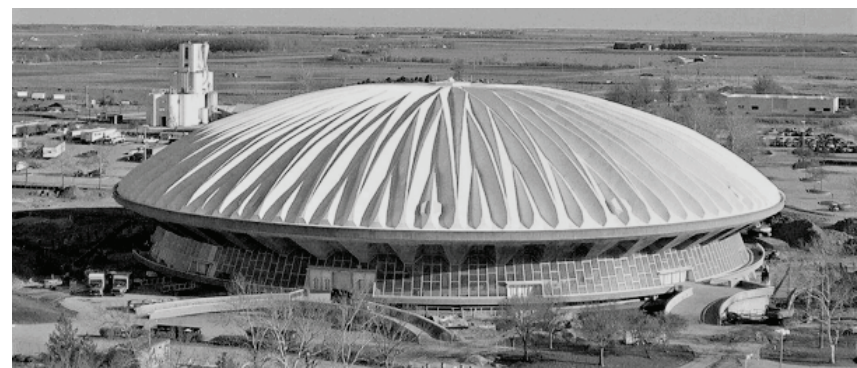

Figure 2. UIUC Stadium, Champaign, 1963; Max Abramovitz, architect, and Amman \& Whitney, engineer. http://statefarmcenter.fightingillini.com/.

first of their kind in the United States - influencing much of his future work. Looking back on their time together at Amman \& Whitney, Abba Tor - noted engineer and friend of Raj-described their supervising engineer: "[Boyd Anderson] made us look at structure as a breathing, living, dynamic, moving and sometimes even mischievous, creature. We all got rid of the notion of 'statics' and its corollary 'make it stand up'. Our real job was to 'tame' the structure-allow it to move within limits without affecting its serviceability in the process."

A major project that Raj worked on was the folded-plate dome for the University of Illinois, Urbana-Champaign, designed by Max Abramovitz in 1963 (figure 2). Raj worked on the dome while Abba Tor worked on the seating. Proposing an alternative configuration to the folded plates to give sufficient strength to the dome, Raj helped redesign the largest edge-supported structure in the United States of its time, spanning 192m (630ft) and tapering to a thickness of only $9 \mathrm{~cm}(3.5 \mathrm{in})$ at its center. Raj also helped design the hangars for TWA in Philadelphia, in 1956 , one of the first cable-suspended roof structures in the United States. These projects eventually formed the foundation of Raj's work in structural design. Reflecting on Raj's work after Amman \& Whitney, Abba Tor writes, "I kept abreast of and admired Mahendra's many innovative projects in India...What I saw in his structures was the continuation of a growth process that started in those exciting years of induction at Ammann \& Whitney," (Raj et al. 2016).

Mahendra Raj's final project with Amman \& Whitney was a pavilion designed by Minoru Yamasaki for the US government to be built at the 1959 Agricultural Trade Fair in New Delhi. During construction, Raj had a chance encounter with Indian architect, Charles Correa. As Raj recalls, "One afternoon at the construction site a tall, handsome young man walked up to me and asked, 'Are you Mahendra Raj? I am architect Charles Correa from Bombay. While in Chandigarh I learnt about you as an engineer who worked on Le Corbusier buildings...I have sought you out and come to meet you to suggest that you don't go back but stay in India and work here. The country needs engineers like you.'" After completing the pavilion, Mahendra Raj was faced with a number of options: he could return to work with Amman \& Whitney, he could take up an offer to join Minoru Yamasaki's office, 
he could rejoin the Punjab Public Works Department, or he could open his own practice in India. Raj, once again, elected to work in India.

Our common objective was to set up practices here, find our own roots and rise to the same stature that other countries had attained. We sought an Indian idiom that expressed our ancient culture but was in tune with modern times...For us engineers, there was the exposure to the new materials of concrete, steel, and precast concrete.

-Mahendra Raj, Domus, 2011

\section{TAGORE MEMORIAL HALL | AHMEDABAD | 1965 | WITH BV DOSHI}

Located on the sandy soil riverbed of the Sabarmati River, Tagore Memorial Hall was built to honor the first non-European to win the Nobel Prize in Literature: the poet, novelist and philosopher, Rabindranath Tagore. Tagore was a critic of the British Raj and authored both the Indian and Bangladeshi national anthems. Tagore Hall is located across from Le Corbusier's brick-clad Sanskar Kendra Museum, and was designed by renowned Indian architect and former employee of Le Corbusier, Balkrishna Doshi. This project was a close collaboration between Raj and Doshi, and one of Mahendra Raj's first major commissions. This project also showcases Raj's capacity for visualization that made him a unique and highly sought-after collaborator. During a conversation with Raj, Doshi states, "Your thinking is not the same as of an ordinary engineer. Sound knowledge of mathematics gives you an advantage. In addition, there is the capacity of visualization. I presume strong mathematics and a capacity to visualize gives you an advantage as an engineer," (Doshi 2016).

From the very beginning, Raj practiced a methodology of divergent thinking - providing options informed by structural performance and material efficiency while fulfilling architectural intention. Ultimately, Raj presented Doshi with twelve options for the structural system based on a continuing conversation

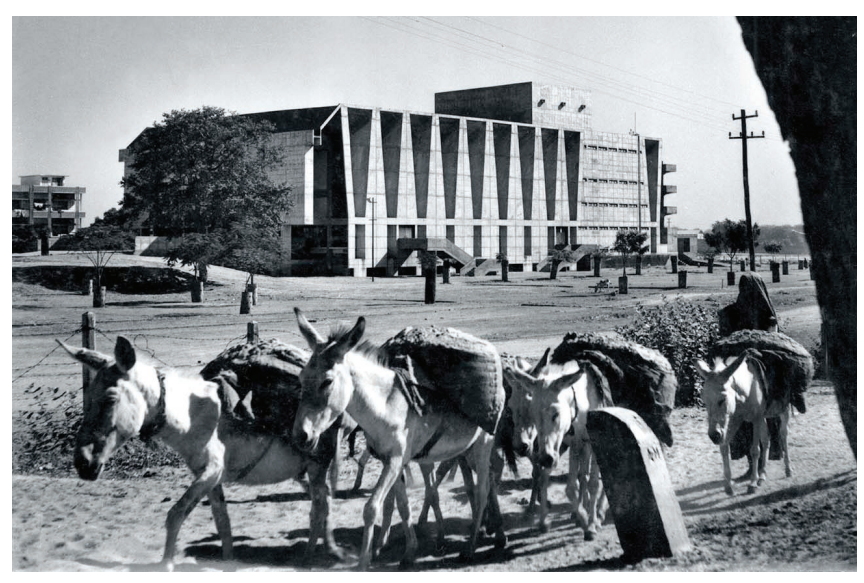

Figure 3. Tagore Memorial Hall, exterior. Vāstu Shilpā Consultants, 2018. between the two. As Raj states, "It was Doshi, the architect, who made the final selection of the form after I had provided some alternatives...There were different concepts, expressing what sort of columns, plates, etc. would be there. The final concept evolved after a number of studies. When we tried to evaluate them, we used manual calculations for deriving the dimensions. Of course, without dimensions there can be no studies."

The project was imagined as two separate structures, the exterior envelope separated from the auditorium seating bowl within. The designers ultimately decided on a system of folded plates forming rigid frames for the external envelope, the first of its kind in India. Designed as carefully proportioned trapezoidal folded plates, the angles and plate thicknesses vary to meet the calculated stresses, moments, and forces without sacrificing material efficiency. The vertical folds reach a height of $17 \mathrm{~m}$, with a depth of $1.15 \mathrm{~m}(5 \mathrm{ft})$ at lintel height and expanding to $2.4 \mathrm{~m}(8 \mathrm{ft})$ deep where they meet the roof. The horizontal roof folds are $2.4 \mathrm{~m}$ (8ft) deep, span $33.5 \mathrm{~m}$ (110ft), and decrease from a thickness of $15 \mathrm{~cm}(6 \mathrm{in})$ at the supports to $10 \mathrm{~cm}(4 \mathrm{in})$ at mid-span.

The seating bowl inside was designed to seat 700 people, and was supported on an independent structure expressed in the main lobby. Sculptural columns twist upwards to support deep cantilevering beams that echo the folded plates of the external structure. Like the folded plates, the auditorium's seating bowl structure showcases the flow of forces and moments. Raj admits to "borrowing" the twisting columns from Pier Luigi Nervi, whom he visited on his way to the United States, and states, "It is very interesting to change the columns to suit the forces. For the Tagore Hall we wanted the column to be aligned with the rib and the rib had a cantilever and that would give it a moment, and we didn't want to take that moment to the foundations... by twisting it the moment carrying capacity of the column got reduced below, became high above; that is what we wanted, that the moment should disappear by the time it reaches the ground." Doshi responds, "I think it was always in your mind to make connections natural."

\section{HALL OF NATIONS \& HALLS OF INDUSTRIES | DELHI | 1972 | WITH RAJ REWAL \& KULDIP SINGH}

The most iconic project in India at the time of its completion, these were the only cast-in-place concrete space frame structures in the world; and while Mahendra Raj was vital to their realization, his impact did not necessarily extend to their design. A competition was launched by the Trade Fair Authority of India (TFAI) to create one large exhibition hall called the "Hall of Nations," and four smaller ones labeled the "Halls of Industries" The brief required a main hall that was column-free and unobstructed, $6,700 \mathrm{~m}^{2}\left(72,000 \mathrm{ft}^{2}\right)$ in floor area with a height of $30 \mathrm{~m}$ (100ft). The four smaller halls would add an additional $7,500 \mathrm{~m}^{2}\left(80,720 \mathrm{ft}^{2}\right)$ of unobstructed exhibition space. The project needed to be planned, designed and constructed within 22 months, requiring close collaboration between the architects and engineers. As Raj recalls, "The 


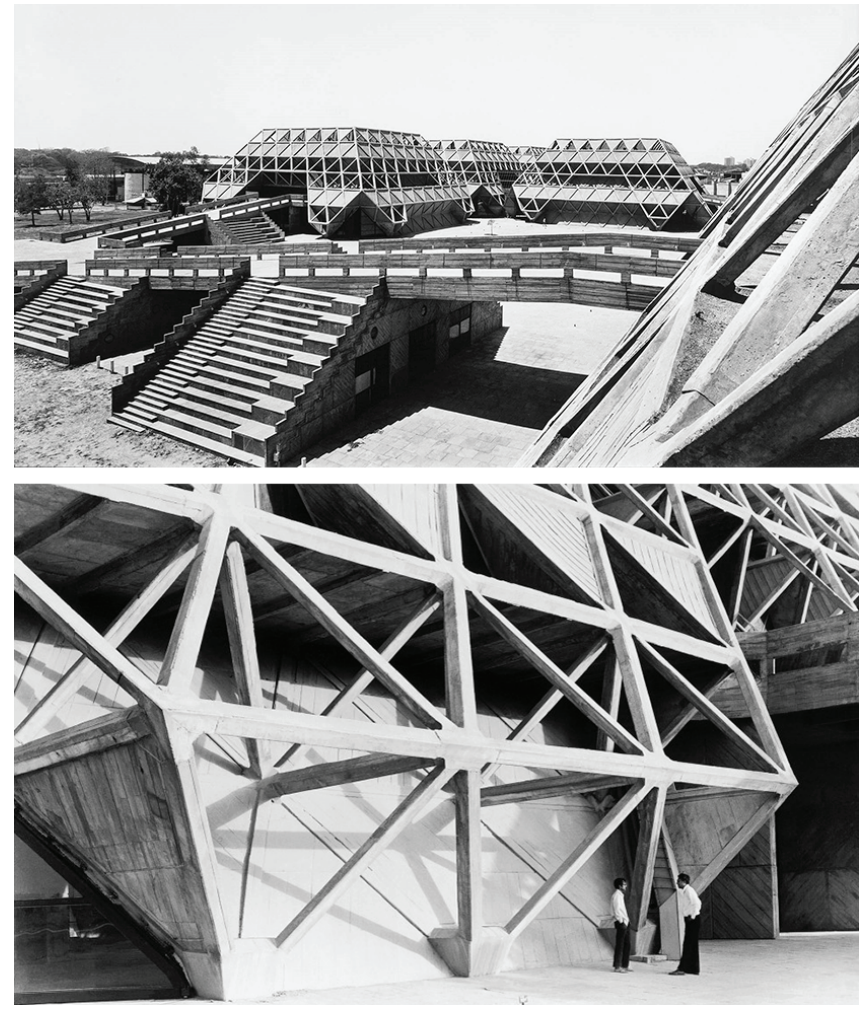

Figure 4. Halls of Industries, exterior; exterior close-up view of cast-in-situ structural joints. University of Chicago Press, 2016.

Hall of Nations was a competition which nobody won. Did you know that? There was a deadline in which it had to be constructed. Raj Rewal's design was a huge hollow space frame, a large rectangle or square, inclined building; so inclined that the jury found it the most attractive, but they thought it was not workable...The building is perhaps unique; it cannot be repeated, and will not be repeated" (Paumier and Raj 2014).

The final shape was determined as an economical solution by the architects - a system of truncated pyramids that could be used for each exhibition hall regardless of their size. The Hall of Nations would have a base dimension of $73 \mathrm{~m}$ by $73 \mathrm{~m}$ (240ft) while the Halls of Industries had a base dimension of $40 \mathrm{~m}$ by $40 \mathrm{~m}$ (130ft) - and the same structural system needed to be used for all of them. Folded plates, doubly and singly-curved shells, lamella frames, and more were considered, but none could span the largest exhibition hall without becoming too unwieldy. Finally, the space frame was determined appropriate for the spans while suiting the needs of both the large and small halls. Relating to the language of the truncated pyramids, the spaceframe would be composed of equilateral pyramids, creating a geometrical language that suited the programmatic needs of openings and enclosure.

Importantly, this project showed Raj's ability to foresee the sequence of construction. Structures undergo stresses during construction that are vastly different upon completion, and Raj understood this well. He often composed drawings of the construction phases that were nearly as thorough as the drawings for the final structure. For the Hall of Nations, Raj determined that scaffolding would be necessary until level five, where the structure becomes self-supporting and eliminates the need for ground-supported scaffolding and frees up the ground for other work. Having no access to a computer that could evaluate such a large structure, the structural design work was done by hand assuming pinned connections at joints and evaluating multiple loading conditions throughout the process of construction.

Typically, spaceframes are designed as assemblies of similarly sized steel elements. Mahendra Raj and his team had no access to the commercially licensed space frames at the time so the material selection, joint design, and mode of construction was entirely up to them. Structural steel and reinforced concrete were each considered but it was ultimately determined that steel would be at least $30 \%$ more expensive than reinforced concrete. Because there was no precedent for reinforced concrete spaceframes, they hesitated to use concrete, but they found that it would be difficult to procure steel at the quantity and within the time frame they needed. As a result, the design moved towards pre-cast concrete elements and joints that would be assembled on site with steel endplates. As design proceeded and the joints and elements were sent out for contractor bidding, though, the designers found no contractor confident enough to design the pre-cast elements to the precision required for onsite assembly. Thus, the Hall of Nations and Halls of Industry became the first cast-in-situ reinforced concrete spaceframe structures in the world. The system was designed with rhomboid element crosssections $25 \mathrm{~cm}$ (10in) deep with a cross-sectional area of $585 \mathrm{~cm} 2$ (90in2) and robust joints that could handle as many as twelve elements coming together. Once again, Raj's ability to visualize came through as he developed - by hand - three-dimensional drawings of complex rebar placements within the joints to balance their compressive and tensile forces.

\section{HINDON RIVER MILLS | GHAZIABAD | 1973 | WITH KANVINDE \& RAI}

The Hindon River Mills project is often associated more with Mahendra Raj's name than with Kanvinde \& Rai. This may be because it was Raj that determined the design of the mill buildings, once again designing a novel system never before seen in India. Designed for the Delhi Cloth Mills company, the resulting design is an aesthetic solution to a series of structural and functional problems. Textile mills often require enormous quantities of humidified air and obstruction-free space, and the initial program required a layout of $21 \mathrm{~m}$ by $18 \mathrm{~m}$ (70ft x 60ft) bays for machinery. Past mills built by the industrial consultants, Gherzi Eastern, used hollow box girders and joists. This is what Kanvinde \& Rai had initially planned on doing. But when Raj was brought into the project as a structural consultant, he recounts, "Seven alternative structural schemes were made for the initial flow diagram and layout which required a $21 \mathrm{~m} \times 18 \mathrm{~m}$ ( $70 \mathrm{ft} \times 60 \mathrm{ft}$ ) bay. Subsequently, the client revised and enlarged their requirement to two sheds of $49 \mathrm{~m} \times 223 \mathrm{~m}$ (160ft $\times$ 730ft) each." 

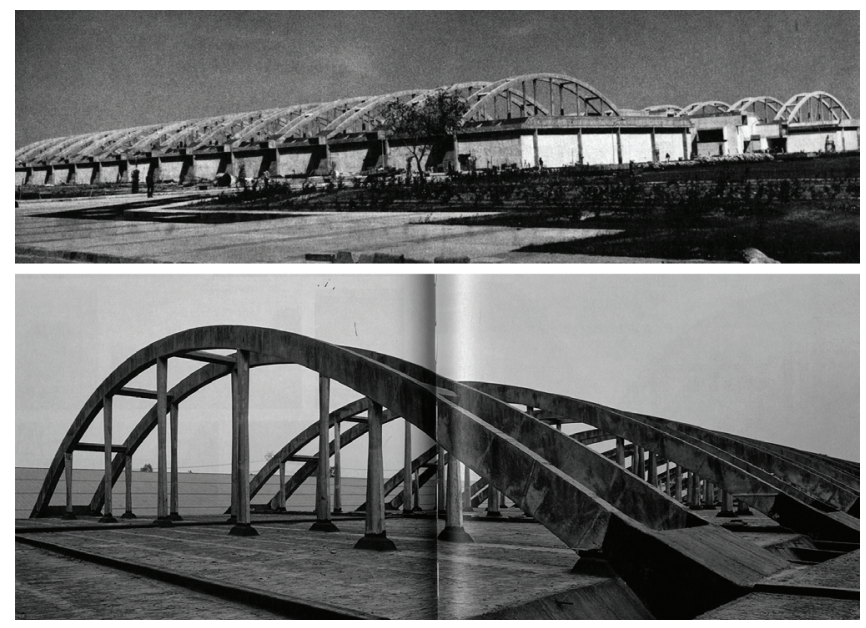

Figure 5. Hindon River Mills, exterior; rooftop structure. University of Chicago Press, 2016.

With this change in span, Mahendra Raj decided to propose a new layout, "Since the earlier system started getting uneconomical at $24 \mathrm{~m}$ ( $80 \mathrm{ft}$ ), we said, 'Why not try to span $48 \mathrm{~m}$ (158ft) with a system suited to that larger span, if we could manage within the same cost?' So we tried a series of alternatives...The whole structure is integrated now and the deck, arch, and hangars all act together." Conceived of as a series of bridges, Raj designed a system of twin arches that suspend the roof panels from concrete-encased steel cables. He found that he could double the span while keeping the relative cost below that of the original system.

The twin arches have a rise of $9 \mathrm{~m}$ (30ft), with cross-sections of $38 \mathrm{~cm}$ by $113 \mathrm{~cm}$ ( $15 \mathrm{in} \times 45 \mathrm{in})$ at the springing point, decreasing to $38 \mathrm{~cm}$ by $75 \mathrm{~cm}$ (15in $\times 30 \mathrm{in})$ at the crown. A cast-in-place hollow girder, $3.5 \mathrm{~m}$ by $1.5 \mathrm{~m}(12 \mathrm{ft} \times 5 \mathrm{ft})$, is suspended from the arches using high tensile cables that simultaneously post-tension the box girder and act as ties for the arches. The girder is used to carry the humidified air needed for the manufacturing below while supporting the prefabricated roofing panels between bays.

Once again, Raj developed the design of this structure with its process of construction in mind. The formwork was reused whenever possible and the construction was phased to allow for minimal scaffolding during erection - freeing up the ground for other work while the roof was completed. For instance, the girders and columns were built first and then enough cables were attached to the girders and pre-stressed to carry the self-weight of the arches and girders before the arches were cast, allowing most of the scaffolding below the girders to be removed.

\section{CONCLUSIONS AND REFLECTIONS}

Mahendra Raj has a body of work that mirrors the growth of a young modern nation from birth to maturity, and throughout his career he has worked with the most noted Indian architects to craft a uniquely Indian identity. When asked about the role he plays in all of this, he limits himself to pragmatic explanations of cost, scarcity of means, and the architect's desires. Yet it is undeniable that much of India's modernist icons would not have been possible without Raj's ability to bring the structure into crystal-clear focus, making it a vital element of the architectural statement.

The projects discussed in this paper demonstrate Raj's ability to make structure integral to his projects, despite the varied natures of his collaborations. In Tagore Memorial Hall, Raj plays equal partner to Doshi throughout the design process. In the Hall of Nations and Halls of Industries, Raj resolves the architectural intent outlined by the Rewal and Singh and then rationalizes and realizes it. In the Hindon River Mills, the architecture materializes as a result of Raj's influence, accomplishing programmatic needs through elegant structural solutions. The technology of construction ties the disciplines of architecture and engineering together, and Mahendra Raj demonstrates time and again that he could elevate this technology beyond the purely technical.

In a conversation with architect and writer, Sanjay Prakash, Raj discusses his method of working, "I get the greatest joy in the concept and analysis stages. The initial meetings in any project are often sketch-based and interactive.... Looking back, I think that most of our projects have worked because we have explored all alternatives before selecting the optimum solution in terms of strength and economy," (Prakash 1986). These two manners of working through sketch and developing alternative designs are what make Mahendra Raj a rare and desirable companion to architects. Throughout his career, Raj maintained that the healthy collaboration between consultants and designers made his work possible. As Prakash writes, "His work seems to proclaim the seldom remembered fact that buildings are created by teams of architects and engineers, managers, builders, workers, and users - and there need be no leaders and followers in this effort for the best results. It is a humbling truth."

\section{REFERENCES}

Doshi, Balkrishna Vithaldas. "A Conversation between Architect BV Doshi and Mahendra Raj, extract from the book - The Structure: Works of Mahendra Raj." Architecture Design 33, no. 11 (2016): 104.

Paumier, Stephane, and Mahendra Raj. "Engineer's Narration, Architecture Can Listen." Domus 3, no. 7 (2014): 23.

Prakash, Sanjay. "Structural Poetry of Mahendra Raj." Architecture Design 3, no. 1 (1986).

Raj, Mahendra, Vandini Mehta, Rohit Raj Mehndiratta, and Ariel Huber, eds. The Structure: Works of Mahendra Raj. Zurich: Park Books, 2016. 